\title{
DOCUMENTOS INÉDITOS PARA LA HISTORIA DE MAGALLANES DIARIO DE VIDA DE WILLIAM BLAIN OVEJERO EN TIERRA DEL FUEGO (1891-1898)
}

\author{
Introducción y notas \\ por Mateo Martinic B.
}

La vida de la peonada rural en la Patagonia austral y la Tierra del Fuego ha sido y es una materia a la que, en general, se ha prestado escasa atención hasta el presente y, cuando ello ha ocurrido, ha sido sólo para su uso como argumento en la literatura regional, en especial en la referida a los géneros del cuento y la novela, donde han destacado autores tan famosos como Francisco Coloane, entre varios. Es posible que tal haya sucedido porque puede estimarse a priori que la gente campesina no "hace historia", con olvido de que, por el contrario, en el vivir cotidiano del mundo rural hay un acervo riquísimo de información de variada clase que resulta indispensable para el mejor y más completo conocimiento de la sociedad en diferentes épocas.

La afirmación es particularmente válida en cuanto se refiere al tiempo del poblamiento inicial del ámbito rural realizado principalmente mediante la crianza ovina extensiva a contar de 1878-80 en lo tocante a Magallanes. Respecto de ello, hasta ahora es poquísimo lo que se sabe acerca de las características, circunstancias y demás del trabajo rural. La preocupación en la materia se ha centrado en el origen de la colonización, en la descripción, el análisis, los resultados y la importancia del fenómeno como factor de desarrollo económico y de adelanto regional generalizado y, para ello, basta recordar nuestros propios estudios e investigaciones. La omisión consiguiente referida a los hechos individuales o colectivos de los protagonistas, excepción hecha de los correspondientes a los pioneros que acometieron la esforzada empresa colonizadora, se fundamenta más que en la infravaloración de aconteceres vitales propios de gente anónima, sencilla y rústica, en la carencia de antecedentes que informan y hacen posible su debida consideración y apreciación. Apenas se conocen algunas consideraciones puntuales o generales complementarias para la mejor comprensión del fenómeno que se ha mencionado $y$, salvo excepción, correspondientes a períodos posteriores al tiempo de la colonización inicial, esto es, el primer cuarto de siglo de su vigencia.

Esa carencia, virtualmente absoluta hasta no hace muchos años, está dejando de ser tal en la medida que se van conociendo noticias personales en forma de relaciones epistolares $y$, sobre todo, de diarios de vida que abundan en datos valiosos que, sumados, permiten hacer luz sobre la vida campesina de antaño, la de los peones, en la época de que se trata. El primero, hasta donde sabemos, en revelar detalles de ese suceder vital fue James Radburne, un inmigrante inglés que llegó a Magallanes en 1892 y vivió en el territorio austral durante los siguientes quince años en parte como trabajador rural (ovejero) y hombre libre, y en parte como fugitivo de la justicia debido a una injusta imputación de que fuera objeto, hasta que, anhelando la ansiada tranquilidad, buscó establecerse por cuenta propia como poblador o colono tierra adentro en el corazón de la Patagonia andina. Fue "descubierto" por el periodista norteamericano Herbert Childs a comienzos de la década de 1930, quien atraído por su fama lo encontró en su remoto asentamiento vecino al lago San Martín, en el oeste del Territorio de Santa Cruz (Argentina), y recogió de su boca su riquísima historia personal, publicada en 1936 bajo el título de 
El Jimmy, outlaw in Patagonia (J.B. Lippincott \& Company, Philadelfia, London). Esa única edición apenas si fue conocida en Patagonia y la historia de su protagonista no demoró en olvidarse, hasta que la obra traducida al español fue publicada por la Universidad de Magallanes en 1997, lo que, por cierto, ha servido muchísimo para enterarse respecto de la materia que interesa.

Un segundo importante adelanto se tuvo posteriormente al conocerse la correspondencia epistolar y los diarios de vida de los hermanos Joe y Gerald John "Jack” Lively, británicos que, como fue de común ocurrencia, arribaron a Punta Arenas por la misma época que Radburne, e iniciaron en el territorio austral una saga personal y familiar aventurera hasta asentarse también como colonos marginales en la zona del lago San Martín. Los diarios y cartas, conocidos recién a partir de 1972, al fallecer Joe, el último de los cinco hermanos Lively, fueron recogidos, comentados y publicados en un libro ameno $e$ interesante escrito por Jorge A. Cramer y publicado bajo el curioso título de Por si quede (Ediciones Photo Design, Buenos Aires, 2006) y que comentáramos en Magallania volumen 35-2 (2007).

Ahora, la amabilidad de Duncan Campbell, nos ha permitido conocer y publicar el diario de vida de William Blain, un escocés que llegó a la Patagonia contratado para trabajar como ovejero en 1891 y permaneció en ella hasta 1898. Durante su estadía llevó un diario con la única intención de dejar sus recuerdos personales a sus descendientes, referidos a su vida y trabajos en un país remoto como era Chile para los británicos de la época. El diario si fue efectivamente conocido por algún familiar del autor, acabó por olvidarse y vino a ser encontrado casualmente entre algunos viejos papeles hace unos años y donados al Archivo Nacional de Escocia.

Antes de proseguir con la materia cabe una digresión necesaria para entender porqué todas las fuentes documentales conocidas proceden de personas de nacionalidad británica. Hay dos razones que lo explican. Una, la del hecho sabido de que los británicos conformaron la mano de obra indispensable, conocedora y práctica, en las estancias ovejeras -fundamento y eje vertebral de la colonización y la ulterior producción económica territorial-, presencia laboral que fue abrumadoramente mayoritaria, $y$ en ocasiones total, en un principio. Ello, como consecuencia natural de la introducción de una explotación económica como era la ovejería extensiva, que si era novedosa en el enorme ámbito estepario patagónico y fueguino, correspondía a un tipo de crianza tradicional en las Islas Británicas (especialmente en la forma practicada en Escocia) habida cuenta de su semejanza geográfica y climática con los territorios australes de América y que, por tanto, requería de trabajadores -ovejeros o pastores- que supieran el oficio criador y pudieran adaptarse a las rigorosas condiciones del medio natural meridional. Así la colonización, en tanto que inversión económica, podía establecerse en la debida forma y redituar a corto plazo hasta consolidarse. Como en el Magallanes de los años de 1870-90 la mano de obra era escasa y más en la especialidad de que se trata, forzoso fue que con las ovejas vinieran los hombres a cargo desde las Islas Malvinas y posteriormente se los contratara en Escocia, de igual modo como en dicha colonia británica se venía haciendo desde mucho tiempo antes, para prestar servicio por tiempo determinado. Así, durante los lustros que siguieron a 1880 los británicos fueron por su número el principal contingente laboral rural y, lejos, el que caracterizaría a ese peculiar segmento de la sociedad de frontera colonizadora y haría tradición hasta nuestros días. Sobre este aspecto particular nos hemos ocupado repetidamente en nuestros trabajos historiográficos, entre los que, para información del lector, sólo mencionamos el libro Los británicos en la Región Magallánica (Ediciones Puntángeles, Universidad de Playa Ancha-Universidad de Magallanes, Valparaíso, 2007), por lo que no cabe abundar sobre el punto.

Una segunda razón explicatoria se tiene en el loable hábito de la inmigración europea de origen septentrional (británicos, alemanes, escandinavos), por razón de instrucción y cultura, de mantener correspondencia epistolar con quienes, familiares o no, permanecieron en los lugares de origen de los emigrados, y, quizá más valioso todavía, la de escribir relatos íntimos, a modo de diarios de vida. Unos y otros documentos, es claro, han devenido de tal modo fuentes únicas y por tanto irremplazables, de vivencias y sentimientos en una época excepcional como fuera la del establecimiento colonizador. El acervo que por razón sumatoria así se va conformando es de un valor informativo excepcional para conocer lo acontecido en el mundo rural de otrora. 
Tras este extenso preámbulo cabe ocuparse en particular del documento que se presenta.

Ya está dicho, el mismo corresponde al diario de vida escrito por William Blain, del que se reproduce la parte correspondiente a su permanencia en la parte chilena de Tierra del Fuego entre 1891 y 1897 . El documento da cuenta de su vida, labores $e$ incidencias cotidianas en un territorio remoto y virtualmente virgen que recién se abría a la explotación económica, luego de definirse la jurisdicción entre Chile y Argentina con el Tratado de Límites de 23 de julio de 1881 que, en lo que interesa, dividió la isla grande de Tierra del Fuego en dos sectores corriendo el deslinde por el meridiano 68 $34^{\prime}$ oeste, desde el cabo Espíritu Santo hasta el canal Beagle, dejando para Chile la parte occidental y para Argentina la oriental. En la sección chilena aunque la ocupación económica había comenzado hacia 1880 con el lavado de arenas auríferas en la zona noroccidental (Boquerón), la misma cobró expresión diferente y mayor fuerza tras la asignación de terrenos para la explotación pastoril, en forma de cuatro grandes concesiones otorgadas entre 1883 y 1890. Tres de ellas, totalizando 1.359.000 hectáreas, quedaron en manos de José Nogueira, empresario de Punta Arenas, que dieron origen a otras tantas compañías para su correspondiente desarrollo. La primera de ellas, The Tierra del Fuego Sheep Farming Company, inició sus actividades en 1890 con el establecimiento de una estancia ovejera, cuyo casco inicialmente se ubicó en la costa de la península Espora, en un paraje conocido como Punta Anegada y que posteriormente, por razones de mejor manejo, se trasladó al interior a un lugar denominado Springhill, de allí que el establecimiento fuera sucesivamente conocido con esas denominaciones y definitivamente con la segunda. Blain, que se desempeñaba como ovejero en la estancia "Monte Dinero" (Patagonia), perteneciente al mismo grupo financiero que se asoció con Nogueira para la explotación de que se trata, fue contratado en 1891 para los trabajos fundacionales $y$, con un corto intervalo, permaneció allí hasta su decisión de retornar a Escocia, lo que ocurrió en 1898*.

El contrato comprendía el pago de un salario de 65 libras esterlinas anuales, más el pasaje de venida y retorno, por un período de trabajo de cinco años.
El diario, escrito en el lenguaje sencillo propio de la gente común, parece no haber tenido otro objeto que el de registrar para sus familiares y la posteridad las vivencias, impresiones y experiencias durante el lapso mencionado. Permaneció inédito y en manos de sus descendientes, conservado con otros documentos personales, hasta que fue encontrado más de un siglo después que fuera escrito y, visto su carácter, donado al Archivo Nacional de Escocia. Allí fue conocido por Arnold Morrison, circunstancia de la que se dio cuenta por Internet y recogido por el señor Duncan Campbell y su esposa Gladys, de Puerto Bories (Magallanes, Chile), que han tenido la plausible iniciativa de buscar y compilar el material documental referido a la presencia británica en la Patagonia. A su gentileza debemos el conocimiento del diario de Blain, que se reproduce con la debida autorización del Archivo Nacional de Escocia. Cabe destacar el interés y amabilidad de los esposos Campbell, así como la autorización de la dirección del Archivo mencionado para hacer la publicación que nos ocupa. La traducción del inglés ha sido hecha por la señora Rosamaría Solar Robertson.

El Diario está complementado con un vocabulario formado por ciento tres palabras en lengua sélknam, que se presenta con su correspondiente significado en inglés y, para el caso, en español (con la grafía que sugería su interpretación auditiva); y, además, con una lista de veinticuatro nombres propios, de hombres y mujeres, recogidos, como el vocabulario, durante la relación circunstancial de Blain con algunos indígenas. Consideramos de interés su transcripción para los efectos de su comparación con los antecedentes proporcionados por otras fuentes etnográficas conocidas (v. gr. el misionero P. José M. Beauvoir), como un aporte enriquecedor de la etnografía sélknam.

Si valioso este complemento, cuánto más lo es el Diario propiamente tal, en tanto que fuente auténtica y fidedigna que da cuenta de impresiones, observaciones y experiencias de un hombre común que informa sobre la vida de los trabajadores rurales durante la etapa fundacional de la colonización pastoril, con lo que de suyo ya es un aporte que aumenta un acervo todavía escaso, y, en el caso, con el añadido de noticias que dan cuenta del conocimiento y trato amigable con los sélknam de las parcialidades septentrionales de la Tierra del Fuego. 
Es en este aspecto particular que valorizamos especialmente los escritos de Blain, por cuanto brindan información sobre la índole y las costumbres indígenas en la etapa de su existencia histórica en que recién recibían la presión ominosa de una cultura extraña, así como sobre la relación que inicialmente se dio entre los aborígenes y los foráneos que se asentaron en su territorio y que, lamentablemente, derivó en enfrentamiento por el choque inevitable de dos culturas, con el trágico desenlace para los indígenas que es históricamente conocido. Hay por ello en el contenido del Diario, datos y pistas que ayudan (y ayudarán) a comprender la forma de conducirse de los sélknam frente a los bienes -ovejas- de los colonos y la consiguiente reacción de los mismos ante la actitud indígena. Así, por ejemplo, nos parece de especial interés el que la respuesta de aquéllos ante las tropelías de los indios -robo de animales- no fuera de inmediata agresión represiva, sino de una suerte de entendimiento recíproco, a pesar de la obvia dificultad de comunicación lingüística, que permitiera superar las situaciones de conflicto. Este antecedente, valioso por demás, hace (y hará) posible reformular consideraciones acerca de la conducta de los civilizados frente a los aborígenes.

Como ya se ha hecho habitual en trabajos de la especie, apostillamos el texto original con notas explicativas que ayudan a su mejor comprensión.

Cabe reiterar el agradecimiento al Archivo Nacional de Escocia por permitir la publicación del Diario de William Blain, así como a Gladys y Duncan Campbell por su amabilidad para compartir la información histórica que, sin más, entregamos al conocimiento de los lectores.

\section{DIARIO DE VIDA DE WILLIAM BLAIN, OVEJERO EN TIERRA DEL FUEGO* (1891-1898)}

Entre las propuestas mencionadas en $\mathrm{mi}$ último [ilegible] iría a Tierra del Fuego a desempeñarme como sub-administrador de Mr. Wales, quien estaba comenzando allí una gran hacienda

Traducción de Rosamaría Solar Robertson. ovina. Mr. Wales ${ }^{1}$ me hizo una muy buena oferta, buena pese a que no podía aceptarla antes de saber cómo era el lugar. Fue dispuesto que lo encontrase en Punta Delgada, cruzase el Estrecho de Magallanes en una de sus goletas. Llegué por primera vez a Tierra del Fuego bien avanzada la tarde, en el lugar donde llegamos había un amplio galpón para almacenar cargamentos, una caminata de alrededor de media hora nos llevó a una buena casa habitación conformada por tres piezas, una destinada a quienes estuviesen a cargo, las otras para los peones o trabajadores, con un corral pequeño, unos pocos caballos, dos yuntas de bueyes, era el asentamiento cuando llegué ahí . A unas tres horas de viaje al interior había dos hombres viviendo en un cobertizo para contener el avance de los indios.

La mañana después de llegar Mr. Wales y yo iniciamos temprano la jornada para echarle un vistazo al campo, durante todo el día nuestros caballos casi no pudieron avanzar, donde hubiese algún rastro de pasto el suelo estaba tan infestado de cururos $^{3}$ que nuestros caballos mantenían el

1 Referencia a Mont E. Wales, quien en 1890 actuando como representante del grupo ganadero-financiero británico Waldron \& Wood, y a nombre propio, había convenido con el empresario de Punta Arenas José Nogueira la formación de la Sociedad Nogueira, Wales \& Co., después The Tierra del Fuego Sheep Farming Company, el traspaso de la concesión fundiaria que el primero había obtenido del Gobierno de Chile sobre la parte norte de la Tierra del Fuego (180.000 hectáreas), entidad que a poco andar inició la explotación de la estancia "Punta Anegada" (después "Springhill") con la introducción de ovejas procedentes de la zona patagónica del estrecho de Magallanes (Peckett Harbour) y las islas Malvinas.

2 Referencia al paraje litoral conocido como Creek, que sirvió como caleta para el desembarco de materiales y animales, y para la erección de las primeras instalaciones de la estancia.

3 El cururo (o coruro), Ctenomys magellanicus, es un pequeño roedor otrora muy abundante en Patagonia y Tierra del Fuego. Animal de hábitos fosoriales su presencia se advertía por la cantidad de orificios de entradas o salidas de sus cuevas y galerías, circunstancia que conocida por los indígenas sélknam, que consumían su carne en abundancia, les permitía cazarlos con facilidad utilizando una argucia práctica muy efectiva, como lo señala Blain. La introducción de la oveja y el constante pisoteo de millares y millares de estos herbívoros a lo largo del tiempo ha sido la causa de una importante reducción numérica de la especie, por la destrucción de sus madrigueras, tanto en Tierra del Fuego como en Patagonia e inclusive su desaparición de distritos como la isla Riesco. 
paso con dificultad, donde no había cururos el suelo era indudablemente estéril. Alrededor de las $3 \mathrm{pm}$ llegamos a una pirámide de hierro erigida por el gobierno chileno como hito en una de las angosturas del Estrecho de Magallanes ${ }^{4}$, donde almorzamos algo. Mr. Wales me preguntó qué pensaba del campo, le dije que si no tenía nada mejor que mostrarme no podría hacerme una oferta que yo fuese a aceptar, él me informó que el campo era mucho mejor en el interior. Le pregunté por qué antes de iniciar la crianza de ovejas había dispuesto su asentamiento campo adentro, tan alejado de la playa. Pronto encontraremos un lugar donde esquilarlas y bañarlas, fue su respuesta. Bueno, dije, pasto y agua es todo lo necesario para comenzar, pero aún deben encontrarse estos dos elementos.

Desde allí avanzamos a través del campo hacia Bahía Lomas a un lugar bautizado Spring Hill por alguien de habla inglesa ${ }^{5}$, eran bastantes leguas de terreno llano, a esta altura el día casi había terminado, así es que sólo tuvimos tiempo para explorar un pequeño rincón de la llanura. Hasta entonces no pensaba que aquella tierra pudiese producir en su estado natural tal cantidad de pastura, había numerosas lagunillas a la vista, pregunté si aquellos eran estanques de agua dulce, lo que Mr. Wales dijo no saber, pero señaló un lugar donde dijo que había un gran arroyo de agua dulce y más allá de éste un lugar llamado pantanos, que significa tierra blanda o pantanosa, había otro río llamado Río Grande o gran río. Luego descubrí que el verdadero Río Grande se encontraba muchísimo más al sur ${ }^{6}$. Había cerros en los tres costados del campo con Bahía Lomas al frente. Cuando me preguntaron qué pensaba del lugar tuve que admitir que era un lugar ideal

4 Desde los años de 1870 el Gobierno Chileno había comenzado la instalación de señales para facilitar la seguridad de la navegación por el Estrecho, en especial de los vapores del tráfico de ultramar (Europa, EE. UU. de América) con las costas sudorientales del Pacífico y viceversa.

5 Efectivamente el topónimo fue impuesto por marinos británicos, al parecer durante los trabajos hidrográficos de la corbeta de S.M.B. Nassau al mando del comandante Richard Mayne R.N., entre 1867 y 1869.

6 En la historia del conocimiento geográfico de la colonización de la Patagonia y la Tierra del Fuego ha sido frecuente la asignación repetida de topónimos como el que se indica, motivados por la presencia de un curso de agua que respecto de otros conocidos con antelación si era más caudaloso o de mayor tamaño, se ganaba el apelativo de grande. para un asentamiento, entonces Mr. Wales decidió de inmediato que allí estaría el asentamiento. Nos tomó casi 3 horas regresar a Creek House desde donde habíamos salido en la mañana. Un acuerdo fue debidamente firmado esa noche sobre el entendimiento de que yo asumiera mis obligaciones lo antes posible. La mañana siguiente volvimos a cruzar el Estrecho de Magallanes hacia Punta Delgada, esa misma noche estuve de regreso en Monte Dinero $^{7}$, algo así como 8 horas de cabalgata, en unos pocos días estaría listo para mi nueva morada. El 28 de marzo de 1891 salí de Monte Dinero con destino a Punta Delgada. Allí embarcamos algunos caballos y cruzamos a Tierra del Fuego. El 2 y 3 de abril se extraviaron los caballos que habíamos desembarcado la noche anterior, mi primer trabajo fue buscarlos. Pensé que lo más probable sería encontrarlos en un lugar cerca de la costa, así es que enfilé hacia la playa. Podía avanzar más fácil y rápidamente no habiendo cururos bajo la línea de alta marea, mientras viajaba me topé con numerosos barriles de baño de ovejas y algunas cajas de azúcar en latas de 7 libras que habían sido arrastrados hasta la orilla por la marea, puse sobre la línea de alta marea toda el azúcar y gran parte del baño. Finalmente divisé los caballos perdidos, estaban tan espantanados que el caballo que yo montaba comenzó a fatigarse, debí renunciar a la persecución y emprender sin ellos mi camino a casa. Los caballos perdidos fueron exitosamente recuperados el 4 de abril.

Me encontré con algunos buscadores de oro que habían estado varios días en el campo intentando hallar caballos extraviados ${ }^{8}$. Estos

7 Denominación tomada del vecino Monte Dinero, una colina del litoral septentrional del estrecho de Magallanes que sin embargo de baja elevación resulta muy conspicua vista desde el mar. De allí su relevancia geográfica. Tal circunstancia hizo que el navegante Fernando de Magallanes la eligiera no bien entró con sus carabelas al gran saco oriental del Estrecho el 21 de octubre de 1520, para enviar a tierra al piloto Juan Carvallo y observara desde su cima hacia el interior para ver cómo continuaba aquella puerta que se le abrió durante su histórica exploración y que a poco andar resultó ser el acceso del paso de mar que intercomunica los océanos Atlántico y Pacífico.

8 Los equinos en la época inicial de la colonización eran un bien inapreciable que debía cuidarse como lo que más. El caballo facilitaba la vida del colono en todo sentido y quedarse sin el animal significaba la reducción del mismo a la impotencia con riesgo, a veces, de la existencia. 
buscadores de oro estaban bien armados y citaron varias ocasiones en que los indios habían sido tanto pendencieros como peligrosos. Algunos caballos parecían naturalmente temerosos de los indios, si los caballos estaban bien y eran bien cuidados, solían regresar a casa cuando los perturbaban durante la noche, pero nunca se podía decir cuándo y dónde se detendrían los caballos ajenos después de llevarse otros consigo. Lo que me urgía comenzar primero era un recinto o potrero para encerrar los animales en la noche. Me instruyeron emplazar uno de alrededor de una milla cuadrada, lo que significaba cercar 4 millas sólo con 3 trabajadores y yo, bajo condiciones muy desfavorables teníamos órdenes de abandonar el lugar. Las pocas personas que nos visitaron recibían una gentil invitación a darnos una mano.

El 12 de abril debía enviar una carta a un lugar llamado Gente Grande 9 , a unas 60 millas de distancia. En aquel momento malamente disponía de dos hombres y caballos, por lo que un chileno ${ }^{10}$ se ofreció voluntariamente para emprender solo el viaje, el viaje de ida lo completó sin desventura, a su regreso desembocó en un campamento indio. Al percibir su error espoleó el caballo y arrancó no antes de que una flecha agujereara una de las orejas de su caballo, dos o tres atravesaran su poncho; esa fue una lección que tuve en mente al enviar desconocidos solos en un viaje ${ }^{11}$.

Descansaba despreocupadamente una tarde de domingo en el mes de abril cuando uno de los hombres vino a decirnos que uno de los caballos de River Side había llegado con la montura vacía; 4 de nosotros cogimos caballos y partimos de inmediato en busca del jinete. Cerca del atardecer dos de nosotros lo encontramos a pie dirigiéndose a Creek House. Montó detrás del otro hombre y nos encaminamos a casa encendiendo fogatas durante todo el trayecto como señal para que los otros dos hicieran lo mismo. No se había oído

9 Este topónimo, situado sobre la bahía homónima, fue impuesto por Pedro Sarmiento de Gamboa durante su viaje de 1580 cuando tuvo el primer encuentro con los sélknam, a los que vio "agigantados"; de ahí la denominación.

10 Los chilenos originarios conformaban la excepción en los trabajos rurales de la primera época de la colonización pastoril, época en la que fue común la presencia de europeos en la actividad, principalmente de británicos.

11 He aquí una prueba de que los sélknam atacaban a los extraños sin mediar provocación de éstos. de ellos al volver a casa, la hora de dormir llegó sin noticias de nuestros compañeros, esa noche me sentí intranquilo por su seguridad y decidí continuar solo la búsqueda de los hombres, pues aún me encontraba limitado de caballos. Salí al despuntar el día, armado con un rifle de repetición y un revolver de 6 tiros. De cualquier manera, me crucé con ellos a dos o tres leguas de casa, no habían estado preparados para una noche en el campo, entre el frío y el hambre mezclados con el miedo a los indios habían pasado una noche sumamente incómoda ${ }^{12}$. Había llevado conmigo algo de comida, así es que pude proveerles un desayuno suficientemente bueno dadas las circunstancias, luego iniciamos el regreso a casa alegrándonos de que nada más serio nos hubiera ocurrido.

El 29 de abril Mr. Wales nos visitó por dos días, fuimos a Spring Hill a ver el lugar que yo había escogido para el asentamiento, para ahorrar tiempo la casa de los hombres, el galpón de esquila y el baño de inmersión estarían tan juntos que no se perdería tiempo yendo de uno a otro, lo que era algo a considerar en la temporada de trabajo; él estaba bastante satisfecho con lo que yo había hecho en un corto tiempo, en Spring Hill tanto carpinteros como trabajadores estaban en faenas.

Por aquel entonces los indios habían comenzado a cortar el cerco de los potreros y a llevarse el alambre. Había aprendido que a los indios les gusta mucho un pedazo de alambre para fabricar lanzas útiles para cazar cururos, como norma estos pequeños animales no construyen madrigueras profundas y los indios se reúnen donde sea posible encontrarlos, disimulan silenciosamente cada vez que oyen el más mínimo ruido y clavan la lanza, sólo en raras ocasiones fallan el tiro ${ }^{13}$. Para surtirlos de alambre dejé numerosos pedazos a lo largo del cerco colgando de los postes, nunca se llevaron siquiera uno de los pedazos dejados para ellos, su lugar favorito para cortar la alambrada era a los costados de un poste tensado, lo que me significaba reparar dos extensiones de alambre en lugar de una, no sé si era casual o planeado. Mr. Wales me

12 Las privaciones y sacrificios de los peones rurales durante la época llegaron a ser proverbiales.

13 Buen testimonio de la maestría indígena para la caza de coruros, a que se ha hecho anterior referencia. 
había dado órdenes estrictas de no maltratar a los indios, debíamos tratarlos con buenas maneras ${ }^{14}$. Por un tiempo llevé a cabo estas órdenes al pie de la letra, al ir a sus campamentos los hombres estaban siempre ausentes, las mujeres indias sólo se reían en nuestras caras, mientras más cerca acamparan, más seguido la cerca era cortada. En numerosas ocasiones encontré huellas de indios en la playa cerca del galpón, los caballos venían galopando al corral después de medianoche, los hombres en River Side tenían que encerrar sus caballos y vigilarlos durante la noche. Por lo que había oído y podía ver, otros medios debían intentarse. Con reticencia adopté medidas más severas. Mr. Wales me había enviado dos hombres cuyos sobrenombres eran Divel y Buffalo Bill. Estos dos hombres tenían algo de experiencia en el trabajo de campo, así es que los monté en dos buenos caballos con provisiones para 3 días, los mandé enseguida a despejar el campo de hombres, mujeres y niños sin derramar sangre humana salvo en defensa propia ${ }^{15}$, los perros de los indios, tanto salvajes como domesticados, eran muy numerosos y debían eliminarse sin reserva ${ }^{16}$. Los dos hombres volvieron al tercer día para informarme que habían cumplido mis órdenes y el ataque a los perros había tenido el deseado efecto de desembarazarnos de los indios.

En aquel tiempo, ningún [ilegible] quedaba en Spring Hill, los hombres estaban viviendo en tiendas de campaña, cada hombre fue provisto de un rifle y municiones en caso de emergencia. Aquello que los hombres llamaban "su tiempo propio" fue ocupado en abatir perros salvajes $y$ cazar gansos, flamencos y similares, de hecho algunos hombres disfrutaban más el deporte que el trabajo; cuando podía malgastar mi tiempo los visitaba de improviso. Una mañana, al salir de la casa y sin estar seguro de cuándo volvería, dejé

14 Esta afirmación es notable por lo novedosa, pues permite comprobar que inicialmente los colonizadores practicaron una política de buen trato con los indígenas, al revés de lo que se ha entendido tradicionalmente, sin base alguna, esto es, que su actitud fue desde un principio agresiva hacia los naturales.

15 Vale la reiteración para lo comentado en la nota precedente.

16 Los perros indios eran bravos con los extraños y atacaban a las ovejas, por lo que desde un principio se les combatió sin descanso. un caballo atado para que un hombre reuniera los animales por la noche y encerré otro para la mañana siguiente, esa noche llegué bastante tarde a casa, solté mi caballo y al entrar pregunté si habían amarrado el caballo que necesitaba para la noche, dijeron que no y pregunté por qué, porque les había dejado un caballo sin amansar, uno que nadie excepto un jinete de verdad podría montar. Me dijeron que había pateado sucesivamente a 3 hombres, se había librado de ellos, sacudido los aperos. Era un caballo joven recién amansado, hacía sólo unos días me lo habían entregado como un animal muy manso, eso era todo lo que sabía de él, qué podía esperar de él la mañana siguiente si había sido así de malo en la tarde. Pasó maneado una fría noche de escarcha, cuando llegó la mañana siguiente todos parecían ansiosos de ver cómo me las arreglaba. Cuando estuvo ensillado y listo para salir lo monté rápida y sigilosamente sin mostrar cobardía, para mi sorpresa él acercó su cabeza al pecho y se largó como si estuviera orgulloso de sentir un hombre sobre su lomo. Me tomó un largo tiempo reflexionar que la maldad del animal había sido sólo una excusa para holgazanear durante la tarde.

En esa época estábamos muy escasos de provisiones, teníamos apenas una pequeña cantidad de arroz, algo de té, nada de azúcar. Tenía muy bien marcado el terreno alrededor de Creek House, tan bien marcado que un ganso no estaría a salvo dentro de 500 yardas, no todos los días tenía una posibilidad a esa distancia. El 21 de mayo el "Luisa" trajo a bordo a Mr. Wales con un surtido de provisiones. El 23 acompañé a Mr. Wales a Spring Hill, él piensa que en estas condiciones he hecho maravillas. El 24 de mayo dibujamos los planos para la cocina y el baño de inmersión, el baño está planificado para contener unas 500 ovejas. El 29 el "Luisa" regresó con 4 bueyes de trabajo. El 4 de junio el "Luisa"17 desembarcó algunos vacunos, 5 caballos y unos cuantos capones para carne. El sábado 13 llegó un mensaje de River Side diciendo que ayer los indios los habían desafiado a pelear ${ }^{18}$, hombres, caballos y municiones serían despachados de inmediato. El domingo 14 fui a River Side con

17 Cúter de la flota mercante de Punta Arenas.

18 Otro antecedente novedoso brindado por Blain, que da cuenta del ánimo belicoso de los sélknam y, como en el caso, asumiendo la iniciativa. 
2 hombres y 6 caballos, allí me encontré con 4 argentinos, los 6 emprendimos nuestra expedición, ha escarchado fuertemente varios días, el suelo estaba muy duro especialmente campo adentro, sólo con sumo cuidado avanzamos con nuestros caballos sin estropearlos, por supuesto ustedes entenderán que estos caballos no están herrados como los caballos en casa. Olvidamos llevar un hacha para romper el hielo, nuestros caballos estuvieron sin agua desde temprano en la mañana hasta tarde en la noche. Durante todo el día no vimos un solo indio, aunque no dudaría en decir que los indios sí nos vieron ${ }^{19}$, nos cruzamos con numerosos campamentos donde los restos de sus fogatas estaban aún ardiendo, en los sitios de acampada había grandes agujeros excavados en la cara protegida del cerro, los agujeros tenían unas 18 pulgadas de profundidad, en la noche niños hombres y mujeres se confundían en estos agujeros cubiertos apenas con sus pequeñas capas ${ }^{20}$. Por lo que antes conocía de ellos y por un cuidado análisis de sus campamentos, ese día estuve inclinado a pensar que no podía existir una clase más indigna de personas. Estando el suelo tan duro y el agua fresca congelada resolvimos arrimarnos a la playa para acampar. Divisamos la playa cerca del Río del Oro en la bahía San Felipe, aseguramos nuestros caballos por la noche y luego nos preocupamos de encender una fogata, después de encender el fuego a uno de nosotros se le encomendó preparar la cena mientras los otros reunían leña para mantener el fuego encendido durante la noche. Fuimos afortunados al encontrar una buena cantidad de madera de naufragio ${ }^{21}$, lo que cumplió nuestros propósitos. Después de la cena disfrutamos fumando y bebiendo un trago de mate. Llevamos sólo lo imprescindible, de modo que no teníamos tienda,

19 El teniente de la Armada de Chile, Ramón Serrano Montaner, primer explorador científico de la Tierra del Fuego (isla grande), fue quien destacó inicialmente esta característica de los indígenas de observar (y vigilar) a los extraños sin dejarse ver por éstos.

20 No obstante lo escueto de la información, ella permite comprobar la precariedad de los albergues -meros paravientos- de los sélknam del norte.

21 Desde el comienzo de la navegación mercante por el estrecho de Magallanes se sucedieron los naufragios por razón del insuficiente conocimiento de la hidrografía litoral, varios de los cuales ocurrieron sobre la costa noroccidental fueguina. De allí la causa de la observación. cuando llegó el momento de acostarse otro escocés y yo acordamos dormir juntos, así es que optamos por ubicarnos con nuestras cabezas hacia el viento y nuestros pies al fuego. Por alguna razón que el resto bien conocía, cada uno tenía su propia cama, esa noche escarchó fuertemente, pero mi camarada y yo estuvimos medianamente cómodos, nadie más fue tan afortunado, no pasaba más de un cuarto de hora sin que alguien se levantara a reavivar el fuego y gritar mucho frío ${ }^{22}$, de vez en cuando un perro salvaje empezaba a ladrar y le respondían con la descarga de un rifle. Aunque mi camarada y yo dormimos poco, permanecimos acostados y dejamos que aquellos que necesitaban un cambio se levantaran. Al día siguiente volvimos a River Side con los mismos resultados del día anterior. El 17, cinco de nosotros rastreamos gran parte del campo entre River Side y Creek House sin ver un solo indio. En mi ausencia uno de los bueyes se había perdido, encontrarlo tomó dos días más de mi tiempo. El 20 de junio cortaron la alambrada del potrero, 7 de nosotros salimos en busca de los culpables y volvimos a casa la mañana siguiente sin haber visto un solo rastro de hombre, mujer o niño. El 4 de septiembre la goleta llegó con 7 nuevos caballos, estos fueron enviados a Spring Hill. En otra ocasión encontré 11 cajas de velas, una buena cantidad de aceites refinados para cocinar, más una caja con un gran cuadro y el mástil de un barco. Entonces llegué a la conclusión de que en el vecindario debía haber ocurrido un naufragio ${ }^{23}$. El sábado 11 encontré en la playa un gran barril de ginebra, la que resultó ser de muy buena calidad, la playa estaba sembrada de velas, delicados jabones, papel para escribir en abundancia. Ahora todos los hombres andan con los naufragios en la cabeza. Al ser domingo el día siguiente todos partieron a echar manos a la playa, al atardecer todos los hombres tenían sus dependencias atiborradas con cajas de mantequilla, velas y varios otros artículos muy tediosos de nombrar. Inmediatamente después de la cena todos estaban enganchados con una botella, algunos con vino, otros con algo más fuerte, ahora sabría a qué atenerme.

El lunes fui a Spring Hill, allá los hombres habían dejado de trabajar y se habían llevado

22 Empleo ciertamente curioso de una forma expresiva castellana en español en el original entre hablantes ingleses.

23 Vale lo expresado en la nota 21. 
consigo la mayoría de los caballos para recolectar restos de naufragio alrededor de Bahía Lomas. A mi regreso esa noche encontré todas las manos más dadas al trago y a la pelea que de costumbre en Creek House, al atardecer siguiente un chileno gritó que me apurara porque Andrew estaba matando a Valencia, cuando llegué al lugar de la pelea Valencia estaba tirado, el otro tipo lo sostenía contra el camarote y le pateaba la cara con un par de botas con clavos de herradura. Sin decir palabra lo agarré del cuello y antes de que pudiera darse cuenta qué pasaba lo arrojé en mi propio cuarto y cerré la puerta. Después de acostar a Valencia, un chileno y yo fuimos a ver en qué ánimo estaba Andrew, deliraba un poco pero no tanto como esperaba, antes de intentar acostar a Andrew fui a chequear que los otros estuvieran bien, al regresar a mi pieza Andrew parecía listo y dispuesto a acostarse, en nuestro camino al dormitorio el chileno susurró que Andrew tenía uno de mis largos cuchillos de campo dentro de su chaleco. Le dije que lo soltara, al principio negó tener algo consigo, finalmente renunció y confirmé que no estuviese en posesión de más armas. Esa noche me quedé en el cuarto hasta que todos parecieron dormidos, el chileno tenía miedo de quedarse en la casa, así es que hizo su cama en la carpintería entre unas raspadoras.

El 15 fue un día de reflexión y el término de la borrachera por un tiempo, el 16 todos al trabajo, visité nuevamente la playa por unos pocos días pero no encontré más licores. Los hombres de Spring Hill me dieron pocos o ningún problema después de la primera conversación con ellos.

El 6 de agosto [de 1892] llegaron 200 ovejas, el "Luisa" y el "Rippling Wave"24 arribaron con ovejas, Mr. Wales a bordo. Debido al mal tiempo antes del 14 no pudimos despachar los barcos. Tan pronto como Mr. Wales bajó a la playa fue a River

24 Embarcación velera famosa en la navegación fretana. Construida en los Estados Unidos, varó durante un viaje por el estrecho de Magallanes hacia 1869. Recuperada más tarde, fue armada por José Nogueira quien posteriormente la vendió a Mauricio Braun y Alfred Scoutt, y de éstos pasó finalmente a manos de doña Sara Braun vda. de Nogueira. Navegó hasta 1906, época en que fue varada en la costa de Cabo Negro (Patagonia) por decisión de su propietaria como homenaje a su meritorio y prolongado servicio náutico. Los restos de su proa se exhiben como testimonio patrimonial en la plazuela de la Gobernación Marítima de Punta Arenas.
Side, los hombres habían estado de borrachera por un tiempo y habían perdido algunos vacunos. 17 de agosto, no habiéndose encontrado el ganado Mr. Wales salió a buscar los animales perdidos con una semana de provisiones para 3 o 4 hombres, el mismo día el "Rippling Wave" llegó con otro cargamento de ovejas, antes de desembarcarlas había 71 muertas, ese lote de ovejas había sido arreado durante el día con poco pasto y enjaulado por casi 3 semanas esperando que los barcos lo cruzaran a través del Estrecho. Al término de 3 días Mr. Wales y su grupo regresaron con el ganado perdido. En la noche del 25 la marea alta fue excepcional, parte del potrero estaba cubierto con agua salada, las ovejas no habían probado agua fresca por un tiempo considerable y bebieron compulsivamente el agua salada, en la mañana había rastros de ovejas muertas y agonizantes por todo el potrero. El 27 de septiembre, 4 de nosotros salimos con las ovejas hacia Spring Hill, nunca vi ni he vuelto a ver tantas ovejas débiles en un solo lote, estaban tan débiles y preñadas de corderos que era casi imposible hacer algo con ellas. La goleta está enviando pequeñas cantidades de ovejas, lo que me mantiene atareado casi noche y día.

13 de septiembre. Escuché que los caballos de River Side estaban perdidos, envíe 4 hombres a buscarlos. El 16 los hombres volvieron con los caballos perdidos y 3 muchachos indios, su introducción a la civilización fue como sigue. Primero les afeitaron la cabeza con un par de tijeras de esquila tan cerca de la piel como el filo pudiese hacerlo. Luego fueron llevados junto al encargado del baño de ovejas y con escobillas de zapatos les refregaron el líquido del baño, claro que no venenoso, para eliminar parásitos, finalmente los remataron con jabón y agua. Cubrieron por primera vez su desnudez con las ropas viejas de los hombres, ellos le temían mucho al rifle ${ }^{25}$, las consecuencias de la huida estaban muy vivas en sus mentes, en poco tiempo se acostumbraron a estar con nosotros en casa.

Las ovejas comenzaron a aclimatarse alrededor del primero de noviembre y en el último mes los peones estaban haciendo las cosas a su manera, mirando alrededor encontré muchas cosas que no

25 Esta afirmación prueba que las armas se venían usando contra los indígenas desde tiempo antes. 
hubiera esperado. Uno o dos de los hombres fueron despedidos, todos los españoles que conocía eran aprovechadores $^{26}$. El 6 de noviembre escuché que rastros de ovejas habían sido vistos afuera y salí en busca de ellas, encontré los rastros pero no las ovejas. Al llegar a casa el ovejero me informó que había encontrado 20 corderos sin las madres, la misma tarde aparecieron unos buscadores de oro $y$ dijeron que habían encontrado algunas ovejas muertas, ocultadas por los indios. El 7 el ovejero y yo fuimos para ver si podíamos dar con el rastro. En nuestros recorridos encontramos 5 hembras adultas y 27 corderos, finalmente llegué a un lugar donde habían forzado a las ovejas a cruzar un arroyo y en sus inmediaciones encontré 18 ovejas y cuarenta corderos. El 9 el ovejero encontró 48 ovejas ahogadas en otra sección del arroyo ${ }^{27}$. El 10 de noviembre el ovejero y yo reemprendimos la búsqueda, finalmente encontramos la huella verdadera, pero supimos que los hombres de River Side nos llevaban la delantera; ese día encontramos más corderos sin madre. Al llegar a casa supe que Mr. Wales había llegado del continente, pese a que había intentado quedarse en Creek House durante la noche. Luego vino un mensajero a informarme que habían seguido a los indios por 3 días, cuando se arrimaron a ellos eran tan numerosos que los habían rodeado antes de darse cuenta de lo que pasaba, después de ver el sitio pensé que su escapada había sido prácticamente un milagro. Al ser solicitado en Spring Hill un refuerzo de hombres y caballos envié de inmediato por Mr. Wales (noviembre 12), seis de nosotros dejamos Spring Hill alrededor de la medianoche, nuestra intención era alcanzar su campamento al alba, en la oscuridad pudimos confirmar algunas de nuestras sospechas. El 13 vimos un indio a gran distancia. Regresamos a Spring Hill en la tarde de ese mismo día sólo para saber que los indios habían estado en otra de sus correrías, el ovejero nos dijo dónde podíamos dar con la huella, mientras Mr. Wales y los otros comían algo alistamos para ellos caballos

26 Por "españoles" debe entenderse a los que hablaban castellano, que tanto podían ser chilenos como españoles propiamente tales, quienes también fueron comunes entre la gente de campo en el comienzo de la colonización ovejera.

27 A este "arroyo" se le llamó desde el principio Creek. Estimamos que más que un curso de agua dulce el mismo debió ser una entrada de mar que lo asemejaba a un río. descansados y salieron de una vez con esperanzas de recobrar algunas ovejas, esa noche alcanzaron el campamento indio, acamparon sobre un cerro rodeado por un gran pantano, los caballos no pudieron cruzar, suponiéndose seguros agitaron sus capas tanto como para decir vengan, un hombre rodeó casi hasta el lado opuesto, se formó una suerte de fuego cruzado y fueron obligados a dejar sus puestos. Cerca de este lugar encontramos un gran número de ovejas muertas y ninguna viva. Los hombre después me dijeron que era un misterio cómo se las habían arreglado para matar tantas ovejas en ese espacio de tiempo ${ }^{28}$.

Del amanecer al atardecer pasé varios días reuniendo las ovejas rezagadas que esta vez se habían librado de ellos, decidí marcar los corderos para salvar las ovejas que nos quedaban y poder encerrarlos y vigilarlos durante la noche. De las 6.500 hembras despachadas pudimos marcar sólo 1.200 corderos, pronto levantamos un pequeño corral cerca de la casa, dentro del corral construí una cueva cubierta con planchas acanaladas. Por 3 o 4 noches me senté antes y después de la luna llena en ese agujero, con el rifle de repetición en la mano de 8 de la tarde hasta las 2, algunas veces 3 de la mañana, pasar 6 o 7 horas en un sitio tan diminuto es una posición para nada envidiable, especialmente en una noche de clima frío.

Por aquel entonces llegó de Inglaterra el hermano de Mr. Wales, asumió sus obligaciones en Creek House, lo que me dejó sólo Spring Hill a cargo. La mayoría de las ovejas que desembarcamos estaban demasiado débiles para bañarlas, la sarna brotó como resultado, encerrarlas en la noche empeoró las cosas, hasta la época de esquila nos tomó todo nuestro tiempo al ovejero y a mí mantener a raya la peste. De las 6.500 ovejas recibidas pudimos esquilar apenas 1.636 en el mes de diciembre, en 5 o 6 meses habíamos perdido 4.864 ovejas o su equivalente en libras esterlinas. Una cosa no podía perdonarles a los indios, cuando robaban las ovejas les rompían las patas traseras a cualquiera que no viajara con rapidez, las que eran

28 Esta información que corresponde a una práctica común de los indios, sirve para entender la indignación de los administradores y gerentes de las compañías ganaderas -por lo que entonces valía la oveja- y que más tarde se la tendría por exagerada en cuanto se refería al número de animales muertos. 
luego despedazadas por perros salvajes ${ }^{29}$. En el mes de diciembre, 3 o 4 hombres levantaban una casa en un lugar llamado los pantanos, casi todas las noches venían los indios y arrojaban piedras a sus tiendas de campaña. Del mes del diciembre al mes de marzo de 1893 cada día que podía disfrutar lo pasaba barriendo el campo de perros salvajes, además de aniquilar ovejas estos perros se perseguían unos a otros por todo el lugar. Durante los meses de verano siempre había uno o dos hombres en el campo manteniendo contacto con los indios, esparciendo veneno para los perros y zorros, a medida que los perros salvajes disminuían, aumentaban los zorros, los zorros de Tierra del Fuego serán del mismo tamaño que nuestros zorros y después de jugar a atrapar corderos nuevos había visto hasta 15 muertos al costado de una pequeña colina.

Como a mediados de marzo empezamos a embarcar más ovejas. Estando en Creek House el hermano de Mr. Wales estaba siempre disponible para recibir ovejas y entregármelas luego a mí en Spring Hill. En un corto tiempo tenía más ovejas que las que nuestro pequeño corral podía albergar, así es que tuve que dejarlas afuera durante la noche; en el mes de abril sospeché que los indios atraparon pequeñas cantidades, el 11 de mayo descubrí que los indios se habían llevado una gran cantidad de ovejas, seguí la huella hasta bien entrada la tarde, cuando encontré a los hombres de campo regresando con unas 800 ovejas y once arcos y flechas. Es bien sabido que la última cosa que un indio haría sería desprenderse de sus arcos y flechas, pero visto que yo no había estado presente en el enfrentamiento no daré una opinión del resultado ${ }^{30}$;

29 Antecedente sobre otra práctica indígena y respecto de cuya veracidad se tuvo duda alguna vez.

30 No obstante la ambigüedad de la noticia, es evidente que la misma es una prueba indiscutible acerca de un enfrentamiento entre empleados de una estancia y los sélknam, con resultado $\mathrm{de}$, a lo menos, once hombres adultos muertos. Con esta información, ciertamente valiosa, se confirma lo aseverado antes por James Radburne (en Childs, 1997), en cuanto que un indio jamás se desprendía de su arco, arma a la que debían otorgarle una significación especial como expresión de capacidad combativa y de virilidad. Inclusive se supo de casos en que a algunos muertos fue preciso abrir a la fuerza las manos para soltar el arco. Los arcos, pues, y no las cabezas o las orejas como se ha repetido una y otra vez desde fines del siglo XIX hasta nuestros días, conformaban para los administradores de estancia de la época la prueba de la muerte de indios ladrones de ganado. el 15 del mismo mes encontramos más rastros de ovejas robadas.

El 13 de agosto de 1893 salí de Spring Hill teniendo bastante ya con Tierra del Fuego; el 14 crucé el Estrecho de Magallanes en un buque de guerra chileno, pasé la noche en Punta Delgada, el 16 estaba de regreso en Monte Dinero, allí me brindan siempre una cálida acogida, tenían pocos caballos mansos, para aprovechar el tiempo acepté amansar 8 potros de 5 años, haciendo esto podría irme donde y cuando quisiera.

El 15 de noviembre partí a Punta Arenas, donde llegué el 16; el $20 \mathrm{Mr}$. Fregui ${ }^{31}$ y yo nos embarcamos en un pequeño vapor llamado el "Antonia Diaz"32, destinado a Isla Navarino para buscar unas tierras, el tiempo no era lo mejor que se puede esperar para un viaje, en poco tiempo estábamos entre las islas de las que hay muchas, aunque muchas de ellas son muy pequeñas, así muy cercanas con cumbres altas, cubiertas de bosques en la base achaparrándose hacia la cima y los altos picos eriazos sobresaliendo al final. Cualquier persona que visite por placer aquella parte de América del Sur no se arrepentirá de pasar unos cuantos días entre Punta Arenas y Ushuaia; en Ushuaia hay un pequeño asentamiento con unos pocos oficiales de gobierno. En muchas islas se encuentra oro en cantidades comerciales, cuando una goleta llega con provisiones generalmente tiene a bordo un buen cargamento de licor que se vende fácilmente y el pueblo suele animarse por unos cuantos días. Al otro lado de la isla está la sede de la misión ${ }^{33}$; en el momento en que narro estaba bajo el control del obispo Stirling, nuestro siguiente desembarco fue Isla Navarino, una de las islas más grandes del grupo y a unas 50 millas del Cabo de Hornos; los misioneros han levantado en la isla varias casas de una sala para los indios, además de entregarles un pedazo de tierra para cultivar, en un momento también tu-

31 Referencia a Luis Fique, un argentino contratado como cajista cuando se introdujo la imprenta en Magallanes (1893) y que después se trasladó a Ushuaia donde se radicó definitivamente. Posteriormente pobló campos en Chile (en la costa norte de la isla Navarino) y también en territorio argentino, y se dedicó asimismo al comercio de ramos generales.

32 Referencia al remolcador Antonio Díaz, de la insignia de Nogueira \& Blanchard, después de Braun \& Blanchard.

33 Referencia obvia a la Misión Inglesa en Ushuaia. 
vieron vacas ${ }^{34}$. Cuando allí desembarqué encontré las casas en mal estado, con excepción de una el resto estaban derrumbadas y sus jardines convertidos en una selva, lo que quedaba de sus ganados corría libremente en el bosque, me encontré con numerosas huellas pero no vi nada más de ellos, fue en una de esas casas indias donde Mr. Fregui $y$ yo pernoctamos con un indio canoero y su esposa, la casa no tenía piso, así es que hicimos nuestras camas entre arena y polvo, entre el polvo y el olor estaba lejos de ser agradable, no teníamos opción, un pequeño reparo era mejor que nada visto que no traíamos tienda, comprometimos a dos indios que dijeron que en 3 horas de caminata podían mostrarnos una extensa franja de tierra, así es que la mañana siguiente iniciamos temprano la jornada. Después de subir una montaña empinada por unas 5 horas y atravesar un bosque denso, llegamos a un bosque achaparrado donde era imposible cualquier avance, yo estaba sumamente contrariado con el resultado, almorzamos algo y partimos a nuestra morada nocturna. Esperaba que el vapor viniera por mí esa noche, después de viajar una considerable distancia comencé a dudar de que fuéramos en la dirección correcta, pregunté a mi compañero su opinión al respecto, dijo que no había nada que temer, pues los indios nos llevarían de regreso, caminamos cerca de una hora, yo voy a nuestra derecha, tú puedes seguirme o no como quieras, después de una charla con los indios se decidió a acompañarme, pero podía ver que era más por el miedo de que algo me pasara que por fe en mí como guía. Cerca de la caída del sol alcanzamos la playa a unas 200 yardas desde donde salimos en la mañana, la mañana siguiente llegó y nada del vapor, fui dejado atrás, en este lugar permanecí las siguientes 2 o 3 semanas. Mr. Fregui quería transportar a otra isla unas 500 ovejas, así es que comenzamos la faena con un pequeño cúter, al momento que sacamos todas las ovejas nos encontramos con dos indios que aseguraron poder llevarnos a Mr. Fregui y a mí a un gran campo

34 La mención es interesante pues ayuda a comprender mejor lo que fue el experimento ideado por el pastor Waite $\mathrm{H}$. Stirling para su desarrollo en Leuaia o Liwaia, isla Navarino, (1867) y que sirvió como antecedente directo para el establecimiento misional definitivo en la costa norte del canal Beagle, en la bahía de Ushuaia, en 1870. sin árboles en el otro lado de Isla Navarino. En esta ocasión no era conveniente que me acompañara mi amigo, así es que me marché una vez más con los 2 indios, pernocté la primera noche a una distancia respetable de mis 2 guías, el día siguiente alcanzamos la playa al lado opuesto de la isla ${ }^{35}$ y avanzamos un largo camino por la playa, lo que era mucho más fácil que circular entre los árboles, mientras viajábamos por la playa encontramos numerosas chozas indias, éstas eran largas varas puestas al tope y amarradas en la parte superior con pedazos de cuero, cubierto luego de ramas, junto a cada choza había una multitud de conchas, estos grandes cúmulos me dieron la impresión de que hasta tiempos recientes los indios canoeros habían sido muy numerosos. A lo largo de la playa no había señales de vida humana, pregunté a mis guías qué había pasado con los indios, me dijeron que unos años antes casi todos los indios de Isla Navarino murieron en el plazo de un año, por otras fuentes supe que los indios se contagiaron de una enfermedad espantosa traída por las marineros que bajaban a la playa cuando navegaban alrededor de la isla ${ }^{36}$. Cerca de la caída del sol mis dos guías se detuvieron sorpresivamente y me preguntaron qué quería hacer, les respondí que estaba yendo con ellos a ver la tierra de la que ellos habían hablado a Mr. Fregui, dijeron que por lo que sabían en los alrededores no había ninguna tierra, que me contestaran eso después de casi 2 días de caminata a través de un bosque denso era suficiente como para hacerle perder la paciencia a un santo, a todas vistas la situación me ponía al límite, puesto que la única arma que tenía era una vara firme les di a entender que no estaba en ánimo de peleas, cuando vieron que hablaba en serio se disculparon diciendo que su ración se había acabado. Les dije que había cuidado la mía y ellos debían haber hecho lo mismo, ni un solo

35 Evidentemente esta referencia es equívoca y da a entender de primera que corresponde al sector sur de la isla Navarino, lo que no fue así, ya que los exploradores sólo conocieron una parte de la costa norte de la misma junto a la que hay varias islas pequeñas, una de las cuales fue la efectivamente recorrida y a la que corresponde la referencia.

36 Dato ciertamente interesante que afirma la tesis de la eficacia mortal de las enfermedades introducidas por los blancos entre los indígenas australes, como causa principal de su rápida extinción. 
mordisco conseguirían de mí después de las mentiras que nos habían contado acerca del campo, la única opción era regresar sobre nuestros pasos, caminamos hasta que oscureció, dormí con un ojo abierto al no saber lo que ellos podrían intentar. El día siguiente, durante nuestro viaje de regreso, cada tanto mis 2 guías se arrimaban a un árbol y recogían lo que supuse era un tipo de fruto, del tamaño de una gran manzana silvestre, era de un agradable color rosado con diminutas manchas, atractivo a la vista, probé muchos pero para mí no tenían sabor, así es que los deposité en el suelo como si fueran hongos ${ }^{37}$. Al llegar al lugar acordado encontré a Mr. Fregui junto a otro indio en un pequeño bote esperando para cruzarme a Isla Watts ${ }^{38}$, donde estaban los 2 hombres y las ovejas. En ese momento mis provisiones se habían acabado, mi amigo no había traído nada consigo, todos nuestros deseos estaban del lado amargo, en esos momentos soplaba un ventarrón, nuestra pequeña embarcación no era del todo marinera, después de esperar varias horas intentamos cruzar, mi amigo era sólo un pobre hombre de mar y sintió temor de ahogarse, así es que tuvimos que regresar una vez más, el indio viejo había estado un largo tiempo en Isla Kepple en las Falklands ${ }^{39}$ hablaba bastante bien inglés, cuando supo que yo había estado en las Falklands prácticamente me adoró, dijo que el agua era calma pasada la roca sobresaliente que causaba las rompientes, Mr. Fergui no es bueno arriba de un bote, dijo, pero si tú remas conmigo pronto llegaremos a Isla Watt, así es que hicimos otro esfuerzo y lo conseguimos. Al llegar a Isla Watt los 2 hombres me informaron que vivían de mejillones, se había retrasado un poco el envío

37 Referencia la hongo Cyttaria darwini o "pan de monte", apetecido por los indios como alimento.

38 En realidad islas Whaits, situadas frente a Puerto Navarino, de las que las principales son la Norte y la Sur.

39 Keppel, como es la grafía correcta del topónimo, es una isla pequeña situada en la parte noroccidental de las islas Malvinas o Falkland. En ella funcionó un establecimiento misional de la South American Missionary Society, donde por largo tiempo permanecieron algunos indígenas en plan de instrucción civilizadora, tarea para la que se seleccionó a los mejor dispuesto al aprendizaje y, asunto no menor, al alejamiento temporal de sus lugares de vida. El propósito fue hacer de los mismos el apoyo para el ulterior trabajo misional en el territorio yámana, como efectivamente se hizo a partir de 1867-70. de nuestros pertrechos, mi amigo y el indio se fueron en el bote para hacerle señas al cúter con el propósito de que los cruzaran a Ushuaia y consiguieran pertrechos para los hombres, así es que fui dejado atrás viviendo de mejillones. Finalmente el cúter llegó con provisiones, me embarqué hacia Punta Toro en la otra orilla de Isla Navarino ${ }^{40}$, mientras permanecí aquí comí y bebí en abundancia, ellos tenían un suministro de los mejores vinos que he probado en mi vida. Al tercer día de mi llegada, uno de los caballeros nativos me ofreció a una de sus hijas como esposa, no exigió pago ni ceremonia, poseerla de inmediato era la única estipulación, por decirlo de otro modo, tomarla a ella como prueba. Agradecido decliné la oferta, la tarde siguiente fui informado de que otro grupo la había aceptado agradecido. En Punta Toro había 2 o 3 casas regularmente buenas, además de tiendas de buscadores de oro, unas pocas chozas indias, con un bosque denso hasta la playa misma, durante mi estadía vi árboles cargados de nieve, aun cuando diciembre es uno de los meses más cálidos del año, en esa parte el clima es muy inestable, a los pocos días encontré que no tenía incentivos para establecer allí mi morada y mientras antes me fuera, más satisfecho estaría ${ }^{41}$. Cerca de fines de diciembre arribó el "Antonia Diaz", subí a bordo y lo encontré repleto de pasajeros, todos los buscadores de oro con destino a Punta Arenas, la muchedumbre representaba un gran número de naciones, con excepción de 2 o 3 ninguno de ustedes se ocuparía de observar una muchedumbre tan tosca ${ }^{42}$. Fuera del puerto el día estaba muy tormentoso y pronto muchos se marearon, éste resultó ser uno de mis días más duros en el mar, así es que tuve la oportunidad de ver lo que otros eran bajo esas circunstancias, no llevábamos un largo recorrido cuando algunos parecían indiferentes a lo que les acontecía, otros rezaban, otro lote más se mantenía de pie y maldecía entre

40 En realidad Puerto Toro, situado en el sector nororiental de Navarino.

41 No obstante lo escueta, es esta una de las únicas referencias hasta ahora conocidas sobre el poblado hacía poco fundado por el Gobernador de Magallanes Manuel Señoret.

42 Apreciación correcta, pues entre los mineros había diferentes nacionalidades aunque abundaban los croatas de Dalmacia (austríacos en la época). 
bocados incomibles, por ese entonces arribamos a Ushuaia, la tormenta se había abatido, desembarqué y tomé té. Alrededor de medianoche salimos hacia Punta Arenas, el resto del viaje tuvimos un tiempo fantástico, cuando llegué a Punta Arenas me encontré en posesión de un buen número de lo que Burns llama piojos rastreros $^{43}$. Al desembarcar fui directamente a un almacén de ropa y pedí que enviaran de inmediato una muda completa a mi hospedaje, entré a una barbería, obtuve un corte y un champú, al llegar a mis aposentos hallé una gran batea que empleé para darme un baño. Después de vestirme con mi nueva indumentaria reuní toda la ropa vieja con excepción de mis botas, la amarré en un atado, la arrojé a un patio trasero entre algunas cajas y otros desechos, habiendo terminado esto volví a ser yo mismo, no sentí siquiera una de mis peores experiencias.

En el mes de julio de $1895 \mathrm{Mr}$. Wales me hizo una buena oferta para regresar a Tierra del Fuego ${ }^{44}$, estando falto de dinero acepté sus condiciones y me despedí tristemente de Monte Dinero el 27 de agosto de 1895. Llegando a Tierra del Fuego fui informado de que los indios estaban lejos de ser tan problemáticos como en 1893, después de echar un vistazo instalé corrales en lugares adecuados en el campo para evitar arrear las ovejas durante millas hasta el sitio de la marca de corderos; realizamos la marca sin tropiezos. Cuando comenzó la esquila, las ovejas estaban en tan malas condiciones por la sarna que fue necesario esquilarlas y bañarlas al mismo tiempo, esto requirió de una doble cuadrilla de hombres, tan pronto como los corderos tenían edad suficiente para ser destetados comencé a separar los sanos de los enfermos, cuando estos últimos fueron traídos y esquilados, el número de ovejas sarnosas era superior a 8.000. El colono ganadero debe enfrentarse a numerosas dificultades entre la pérdida de ovejas y los gastos extras del baño. Un establecimiento nuevo había surgido en Río

43 Referencia al Pediculus humanus capitis. La alusión es para Robert Burns, poeta escocés (1759-1796). Nota de la traductora.

44 Al retornar de su viaje a las Islas Australes, Blain fue a trabajar a la estancia "Monte Dinero" que pertenecía al grupo empresarial ganadero británico Waldron \& Wood. del Oro por ese entonces ${ }^{45}$. Estando Mr. Charles a cargo durante la ausencia de sus hermanos, salimos un día a ver cómo se estaban desarrollando las cosas, alcanzamos nuestro destino después de una cabalgata de unas 30 millas en un frío día de invierno, únicamente para encontrar al encargado del lugar; al estar los comerciantes escasos de materiales se habían ido por un día a Punta Arenas e intentarían regresar con la primera goleta. Los almacenes estaban casi agotados, en el intertanto tuvimos que conformarnos con un sorbo de té en lo que llamaban la casa o rancho de los jefes. Encontramos muchísimos rifles pero sólo 3 cartuchos. Mr. Wales y yo salimos en busca de la cena y el desayuno, a unas 300 yardas de distancia divisamos una cabra salvaje, existían pocas posibilidades de acercarse, de cualquier manera, Mr. Wales lo intentó y falló, al poco andar vimos otra a más o menos la misma distancia, ahora fue mi turno intentarlo, lo intenté sin mejores resultados. Nos quedaba un solo cartucho y nada para cenar o desayunar, a nuestro regreso fuimos afortunados al matar un ganso viejo con nuestra última bala, así es que tuvimos suficiente para esa noche. La mañana siguiente alcanzamos Spring Hill a tiempo para cenar.

Alrededor de mediados de marzo de 1896 fui uno de los cuatro que salieron hacia Río del Oro con 4.000 ovejas, pasamos una noche terriblemente fría en el campo, todo el tiempo debimos mantenernos en movimiento, al alcanzar Río de Oro encontré dos ovejeros de Dumfries esperando mi llegada ${ }^{46}$, cuando los llevé a Spring Hill estaban completamente fatigados, una larga cabalgata es muy agotadora para quienes no suelen montar. Alrededor del 11 de junio de 1896 oímos que algunos indios habían

45 Referencia a la estancia "Philip Bay", fundada tiempo antes para la explotación pastoril de la segunda concesión de Nogueira (aunque nominalmente era de Mauricio Braun), para lo que aquel empresario había constituido con los hermanos Wales una segunda compañía, The Philip Bay Sheep Farming Company, con una participación para los socios semejante a la que había en la primera. El casco fue ubicado en la desembocadura del río del Oro en la bahía Felipe, de ahí que en un comienzo al menos se le diera ambos nombres al establecimiento, binominalidad que se mantuvo por largo tiempo.

46 La práctica de contratación de ovejeros escoceses para la ganadería magallánica ya era un hecho habitual para entonces. 
sido vistos cerca del límite de las ovejas, se envío una expedición en su búsqueda, el grupo regresó el día 16 con alrededor de una docena de hombres, mujeres y unos pocos niños; serían enviados a Isla Dawson ${ }^{47}$. El 26 de junio Mr. Wales partió a Inglaterra, el 2 de julio fueron traídos dos indios más llegando el número a 14. Así es que resolví darles otra oportunidad, después del desayuno me acerqué a ellos para explicarles mis intenciones y mis condiciones, pero encontré que uno de los niños había muerto durante la noche. Conseguí que el carpintero hiciera un ataúd, cuando los padres vieron la tapa atornillada y el cuerpo dentro del ataúd parecieron muy afectados, mucho más de lo que yo había esperado. Al preguntarles si querían ver lo que íbamos a hacer con ello dijeron que sí, así es que los llevamos hacia el sepulcro que estaba bastante cerca. Cuando fue ocupada la sepultura y el pasto pulcramente dispuesto marcharon de regreso a su morada, entonces se les explicó que obtendrían su libertad si prometían comportarse en el futuro y no molestar a los animales; recibirían tanto como lograran llevar consigo, esto lo aceptaron fácilmente, después de darle tanto como pudo comer, cada varón obtuvo media oveja, entonces los dejamos a su suerte sobre el entendimiento de que si ellos rompían su promesa no podrían esperar clemencia alguna de parte nuestra. Unas 2 semanas después, uno de los hombres de River Side vino a decirnos que los indios habían ocupado su refugio cerca de la casa de River Side y él y su camarada les temían a los indios, de cualquier manera, este grupo de indios resultó ser el mismo que yo había liberado a comienzos de julio. Ocuparon su refugio cerca de la casa de River Side, mantuvieron su promesa $y$ pronto estaban en amistosos términos con la

47 Entre la primera y la segunda permanencias de William Blain en Tierra del Fuego, la cuestión indígena, esto es, el enfrentamiento entre los trabajadores de las compañías ganaderas y los sélknam se había agudizado y, como consecuencia, había asumido estado público, con desagradables consecuencias para el prestigio de esas sociedades (de la Sociedad Explotadora de Tierra del Fuego en particular), a las que se acusó de vejámenes crueles y muertes de indígenas. Fue así que cambió la estrategia de las empresas colonizadoras, morigerándose un tanto la violencia y procurándose la captura de los indígenas para su traslado a la Misión de San Rafael (Puerto Harris, isla Dawson), abierta en 1889 por los Salesianos para acoger y cristianizar a los indígenas que sufrían el acoso de los foráneos. gente del campo. Alrededor de fines de septiembre, 5 de los hombres entraron al establecimiento, los alojamos por la noche, les dimos comida en abundancia, la mañana siguiente salieron al camino ${ }^{48}$, cada uno cargado con tanta carne de capón como pudo, unos cuantos días después otros 2 hombres aparecieron, vinieron derecho a mi puerta, allí dejaron sus arcos y flechas y fueron al baño de ovejas donde estábamos ocupados bañando, todos les brindamos una cálida bienvenida, uno de los ovejeros mató un ganso, a cada uno se le dio un cuchillo, lo desplumaron, lo despresaron, cada cual con su parte se dirigió al camino, a todas vistas con el mejor de los ánimos.

En el mes de noviembre, Pike, uno de los trabajadores que recorría los límites del campo, me preguntó si aceptaría a un indio que había dejado su tribu y se había ido a vivir con él, dijo que el indio era tan tranquilo y honesto que no quería ubicarlo junto al resto de los hombres por temor a que lo trataran brutalmente y debido a que se estaba mudando no podía seguir con él a su cargo, como yo tenía bastante espacio disponible accedí a darle una oportunidad. Cuando llegó me dijo que su nombre era Joe, me pareció que Joe era capaz de emplear un número considerable de palabras en inglés, le proporcioné un cuarto privado y le dije que esperaba que él y su cuarto se mantuvieran limpios y ordenados, a los pocos días me sorprendí al ver el interés que mostraba en la casa, nada lo complacía tanto como cuando le pedía que hiciera un pequeño trabajo, al poco tiempo noté que estaba algo débil, quise que tomara azufre una o dos veces al día por unos pocos días, él no me prestó atención, para mostrarle que no era venenoso lo probé yo mismo, incluso entonces se mantuvo firme en su postura, finalmente le dije que lo tomaba o regresaba con los indios, la amenaza fue demasiado para él, prometió tomar la cantidad que yo le había indicado dos veces al día. Alrededor del tercer día le pedí que me mostrara cuánto había sacado del tarro, para mi sorpresa faltaba tanto del tarro como para 10 hombres, cuando le expliqué que había tomado demasiado dijo no, no, me hizo bien, usted buen doctor, el cocinero mencionó que cuando él veía aproximarse

48 Lo de "camino" es una exageración y debe entenderse como lo que era en la realidad, o sea, una simple senda o rastrillada originada en el paso ocasional de personas. 
a cualquiera de los indios, salía, trancaba la puerta y desaparecía con la llave. A los 12 meses el pobre Joe murió de tuberculosis ${ }^{49}$. Sólo pocos, de hecho, ninguno de los onas que conocí sobrevivió un tiempo largo la vida civilizada.

Varios de los indios de River Side querían quedarse en el asentamiento, Mr. Wales tenía a dos de ellos en su casa y les había enseñado a esperar su turno en la mesa, uno de los muchachos demostró inclinación por el dibujo, otro muchacho se entregó al trabajo del campo, el cual posteriormente murió con 50 libras esterlinas de crédito a su favor ${ }^{50}$. En febrero de 1897 oímos que una tribu de indios aparentemente desconocidos merodeaba desde hace un tiempo en las cercanías del campo de las ovejas. Se envió otra expedición de 5 hombres en su búsqueda, después de 6 días en el campo regresaron sin haber visto un solo hombre, mujer o niño. En el mes de mayo los indios de River Side se pelearon entre ellos, muriendo uno del grupo ${ }^{51}$, a comienzos del mes se consideró necesario enviar otra expedición, después de unos días en el campo regresaron con un muchacho indio, con él son 7 los indios en el asentamiento. Alrededor del 14 de mayo oímos que los indios habían robado unas 800 ovejas y algunos carneros ingleses, estos invasores de Gente Grande nunca han respetado a persona alguna, el siguiente turno sería nuestro ${ }^{52}$. El $1^{\circ}$ de julio de 1897 pasamos la noche junto a 5 desconocidos y 11 indios, entre hombres y mujeres, en su estado salvaje se arrodillan alrededor de un

49 Esta mención es particularmente interesante porque, además de confirmar la facilidad con que los indígenas se contagiaban con la enfermedad, demuestra que el mal había penetrado desde hacía tiempo entre los sélknam y se había difundido rápidamente entre ellos. Queda por ver cuál pudo ser la fuente de contagio que, hipotéticamente, atribuimos a los mineros, que fueron los primeros civilizados que tuvieron algún trato, libre o forzado, con los aborígenes. El comentario se hace porque ha solido asociarse la morbilidad (y mortalidad) por la tuberculosis con la internación (y hacinamiento) de los indígenas en la Misión de Dawson.

50 Otro dato notable, pues da cuenta de los sentimientos de humanidad y de seguridad que animaban al empresario colonizador.

51 Las luchas grupales entre los sélknam, ocasionadas habitualmente por penetración en los haruwen ajenos aunque documentadas por varios autores, en especial por Lucas Bridges, han sido infravaloradas como agentes de reducción poblacional.

52 Esto revela, una vez más, que a lo menos hasta esa época, los indígenas podían ser razonables en el trato con los foráneos. gran fuego a no más de 30 yardas de mi puerta con un montón de carne de capón asándose al fuego, todos ellos parecen felices, extrañamente los indios del asentamiento no se relacionan con sus amigos, últimamente hubo varias expediciones, pero todas fallaron en contactar a los indios. Finalmente, uno de nuestros muchachos aclimatados pensó que podía encontrarlos. Alrededor del primero de agosto de 1897 partió otra expedición en busca de los indios con el muchacho indio como guía e intérprete. Durante el segundo día en terreno nuestro guía señaló un lugar a cierta distancia y dijo que los indios debían estar allí o en las inmediaciones, el muchacho partió solo teniendo las instrucciones claras, a su debido tiempo divisamos una multitud de indios acercándose a sus vecinos civilizados, se detuvieron cuando llegaron a cierta distancia de la tienda de campaña, el guía vino a la tienda a informar a Mr. Wales y su grupo que los indios eran amigables. Mr. Wales y su guía se aproximaron a los indios, el guía ofició de intérprete, se les dijo a los indios que Spring Hill, Río del Oro y Gente Grande habían aceptado darles toda la carne que necesitaban bajo la condición de que en el futuro no molestaran a sus animales, cuando lo necesitaran 2 o 3 del grupo debían acercarse al asentamiento más cercano y se les enviaría un suministro de carne, al mismo tiempo se les protegería de los hombres blancos más inescrupulosos. Estas condiciones las aceptaron fácilmente $e^{53}$.

Con el correo de agosto llegó una carta de mi viejo amigo Mr. Sparks, el que me solicitaba una contribución a nombre de uno de nuestros antiguos conocidos, quien estaba de regreso en Londres y se hallaba en una situación apremiante, dado que no podía trabajar, tuve el agrado de enviarle en el correo siguiente un cheque por 25 libras esterlinas desde Spring Hill, Río del Oro y Gente Grande. 14 se septiembre, 2 ovejeros encontraron en el campo a un indio muerto con una flecha colgando de su costado, probablemente el resultado de una riña ${ }^{54} .1^{\circ}$ de octubre, los indios que se rindieron a principios de agosto cruzaron a River Side donde nuestros viejos amigos. Los 2 grupos de indios se trenzaron en un combate fatal, el grupo de los desconocidos dejó 4 muertos en el campo de batalla, mientras varios otros resultaron heridos ${ }^{55}$.

53 Se reafirma lo dicho en la nota 51.

${ }^{54 / 55}$ Aquí se advierte claramente que la razón del enfrentamiento estuvo en la violación de un territorio grupal. 
Poco después de este incidente, los indios de River Side nos contaron que los otros estaban robando ovejas, sabiendo que los dos grupos no estaban en buenos términos pensé que lo mejor era actuar con cautela hasta escuchar lo que el otro grupo tenía que decir, el resultado fue que un grupo culpaba al otro, alrededor de una semana después uno de los ovejeros encontró un lugar donde habían carneado ovejas y enterrado los cueros. Los indios de River Side se enteraron del descubrimiento y uno de ellos se ofreció de voluntario para enseñarnos un lugar donde se hallaba enterrada una gran cantidad de cueros $^{56}$, llevó al lugar a uno de los ovejeros, no lejos de su propia casa, la misma fuente nos informó que en Río del Oro los indios de Bahía Philips estaban carneando muchísimas ovejas. Numerosos hombres fueron enviados a rastrear el campo, la partida de búsqueda pronto reveló un giro inesperado de los hechos, los indios negaron todo conocimiento de tal cantidad de cueros de oveja enterrados en el campo, se les recordó su promesa y fueron advertidos de las consecuencias si obraban mal en el futuro.

El 10 de noviembre de 1897 empezó la marca de corderos. Por ese entonces, la marca era un asunto bastante interesante, como regla general comenzábamos un lunes si el tiempo lo permitía; nuestras tiendas, redes de ovejas y provisiones eran trasladadas en dos carretas de bueyes. El agua para propósitos domésticos era escasa en la mayor parte del campo, esta comodidad debía ser acarreada en barriles junto a un suministro de leña. Quizás 8 o 10 hombres a caballo, principalmente ovejeros con unos cuantos perros, mientras se ordenaban las tiendas y redes los ovejeros entraban un lote de ovejas, listos para comenzar, un hombre era designado como cocinero, los encargados tenían una pequeña tienda privada, el café estaba listo para nosotros al aclarar el día, era mi responsabilidad que los hombres estuvieran en pie, llegaba el momento de movilizarme cuando el cocinero llamaba al café, cuando nombraba la palabra café por segunda vez se escuchaba rezongar a los que no estaban levantados "allí está de nuevo ese viejo Divel”. Si los hombres no estaban listos, con un rebenque me dirigía a los ofensores, esto significaba

56 Está visto que los sélknam habían ideado sus propias estratagemas de ocultamiento de las evidencias de abigeato. que debían vestirse en el descampado a costa de las risas de los otros, por supuesto que había que tener cuidado de no llevar el juego demasiado lejos ${ }^{57}$. Todos parecían disfrutarlo, aun cuando eran largas las jornadas y pocas las comodidades, cuando llegaba la temporada los ovejeros eran hábiles para recordarme el que consideraban debía ser su turno para marcar corderos, durante las tardes de lunes a sábado dos de nosotros marcamos 11.326, lo que es sólo dos menos que 1.870 por día, en 1897 marcamos 16.450 en total. El domingo 15 un párroco escocés celebró un servicio religioso en casa de Mr. Wales, ese fue el segundo sermón que escuché predicar en veinte años ${ }^{58}$.

Mientras tanto los indios de Philips Bay no mostraban respeto por las promesas hechas en el mes de agosto, en vez de dirigirse a los asentamientos por carne, mataban lo que se les antojaba, enterrando los cueros. Se envío otra expedición para cuestionar su proceder, alrededor del 19 de noviembre la expedición regresó con cerca de 40 prisioneros, incluyendo hombres, mujeres y niños, los hombres fueron desarmados y esposados en parejas, las mujeres y los niños no sufrieron más inconvenientes, en las noches eran alojados en un amplio galpón metálico, sólo los hombres eran engrillados, pero recuperaban su libertad a primera hora de la mañana, un hombre con un rifle cargado se mantenía junto a ellos durante el día. Estuvieron prisioneros desde el 19 de noviembre hasta el 13 de enero, cuando se les envío a la misión de Isla Dawson. Ninguno de ellos intentó escapar durante su reclusión. Tuve numerosas oportunidades de observar algunos de sus hábitos y peculiaridades, de estas últimas sólo apunté dos, la primera, su fe en el curandero. En una ocasión en que el paciente fue una joven mujer india la llevaron afuera y la recostaron en el pasto, luego apareció el doctor, quien resultó ser al mismo tiempo sordo y mudo, se extendió sobre ella con la piernas rectas, la palpó completa desde el lomo al nacimiento de la cabeza por intervalos de un minuto, volviendo suavemente al punto

57 Este párrafo permite entender la rudeza de la vida de la peonada rural de ese tiempo.

58 Referencia interesante. Es probable que el pastor de que se trata fuera el reverendo John Williams que tenía a su cargo la capellanía anglicana en Punta Arenas y de quien se sabe que realizó algunas misiones rurales ocasionales. 
inicial, retomó la operación, pero gradualmente se fue entregando al estado más exaltado que pueda imaginarse, quejidos de la paciente entre apretones y torceduras, era más probable que todo terminara en una catástrofe de proporciones que con la cura del paciente, incluso la cabeza de la paciente recibió más tratamiento del que yo le hubiera proporcionado, finalmente las manos del doctor se juntaron con una fuerza considerable, parecía tan rígido que le era difícil enderezarse, sus dos manos manteniéndose sumamente unidas como si se aferraran desesperadamente a algo, luego de efectuar unas cuantas torceduras comenzó a soplar sus manos, fue abriéndolas lentamente y con un salto se apartó de la paciente. El último acto fue disipar la enfermedad o el dolor del paciente, el doctor procedió a arrodillarse en el suelo, pareciendo algo exhausto. La paciente fue alzada y trasladada al interior del galpón, se encontraba bien a la mañana siguiente, ustedes mismos podrán juzgar si la cura fue producto de la ciencia o la $\mathrm{fe}^{59}$. Una mañana, una mujer india entró con un bebé a un galpón en el que teníamos algunos barriles de cal viva, ella se sentó junto a un barril abierto, recostó al bebé atravesándolo sobre sus rodillas, el único abrigo que él tenía era una diminuta venda alrededor de sus ojos, luego de desatar la venda ella se humedeció los dedos en la boca, los sumergió en cal viva y comenzó a frotar la cara y el cuerpo del niño con este sencillo ungüento. Me presenté ante ella y le expliqué tan bien como pude que así era muy probable que dañara al niño pero, como suelen hacer las madres, se consideró a sí misma la mejor jueza, para su propio deleite continúo el proceso de frotado o más bien de pintado, luego vendó los ojos del niño y se reunió con su gente, siendo un niño varón esta frotación o pintura lo convertiría en un valiente guerrero cuando llegara a la adultez, era tradición ceñir por un determinado período una banda alrededor de los ojos de niños y niñas,

Esta información es en verdad notable pues en ella se tiene una descripción verosímil, aunque escueta, de un acto de sanación chamánica, especialmente valiosa a nuestro juicio para la mejor comprensión de la intervención del kon sélknam y de la aceptación de la misma por el grupo familiar del enfermo, y porque además la misma fue escrita simplemente para memoria de un acto de rarísima práctica ante extraños. se suponía que esta tradición mejoraba el sentido de la vista, no cabe duda que estos indios poseen una vista excepcional. No puedo decir si lo que merece el crédito por este utilísimo don es el vendaje de los ojos en los niños o la práctica de la observación desde la infancia ${ }^{60}$.

Alrededor del primero de marzo de 1898, John McQueen, uno de los ovejeros, se fue a Punta Arenas para encontrarse con su novia, quien aguardaba allí proveniente de Escocia. En esta ocasión especial había prometido acompañarlo, pero no pude desocuparme hasta la mañana del 4. La primera noche alcancé Río del Oro; la segunda, Gente Grande, llegando a Porvenir la noche del 6. Como no había arribado el barco con que pretendía cruzar el Estrecho, pasé la noche con un viejo amigo de las Falklands. Esa noche llegaron algunos oficiales del gobierno con los restos de dos hombres muertos por los indios ${ }^{61}$, uno de los cuerpos había sido atravesado por las flechas en 25 ocasiones, los indios de esos alrededores son de los peores de la isla, aquella parte de la isla está densamente cubierta de bosques, posicionarse entre ellos y su refugio no es una tarea fácil; en aquel tiempo el conflicto entre ellos y los nuevos pobladores no tenía fin ${ }^{62}$. El 7 de marzo llegó el barco, en la tarde subí a bordo, llegué a Punta Arenas esa misma noche, siendo la distancia del cruce de unas 20 millas. McQueen no apareció hasta el 10, el correo llegó alrededor del mediodía del 11 trayendo a su amada a bordo, ella fue llevada al hotel donde yo me hospedaba y dejada a cargo de la posadera, como era el único de los 3 que sabía algo de español fui el responsable de llevar a cabo los arreglos para el evento venidero, mientras hacía esto algunos llegaron a la conclusión de

60 La segunda posibilidad parece más razonable como explicación de la agudeza visual aborigen.

61 Referencia a Francisco Cárcamo Díaz, piloto, y a José Asenjo, grumete, ambos de la dotación de la corbeta Magallanes de la Armada de Chile, que fueron atacados y asesinados por los indígenas de la parcialidad de Boquerón en marzo de 1898, cuando los mismos se internaron por los bosques costeros del sector. Blain confirma asimismo la información que daba cuenta de la particular agresividad de esa parcialidad sélknam occidental.

62 Referencia específica a las escaramuzas y enfrentamientos entre los indígenas de una parte, y los mineros y vecinos del recientemente fundado poblado de Porvenir, por la otra. 
que mis días de soltero estaban por terminar, incluso la posadera mantuvo esa impresión hasta el último momento. En la tarde del 13 llegó al hotel un oficial de gobierno con una cantidad considerable de libros y papeles para darle a la joven pareja su licencia matrimonial de acuerdo a la usanza chilena, fue mi ocasión de tomar un rol secundario, casualmente me encontré con un viejo camarada llamado Daily, él era un experto calígrafo y manejaba bien el español, le pedí que fuera uno de nuestros invitados y lo promoví al puesto de intérprete, pero sus deberes no terminaron allí, pues el oficial era tan lento con el lápiz que los libros y papeles fueron entregados a Daily para que los llenara, el oficial fue lo suficientemente rápido para decirnos que su tarifa era de 3 soberanos $^{63}$. Después de la ceremonia, el selecto grupo hizo justicia de una mesa bien servida, las únicas damas presentes eran la dulce esposa, la posadera y su criada, David McCall no permitió que su violín dejara de acompañarnos con canciones escocesas, todos pasamos una noche sumamente agradable ${ }^{64}$. El 15 de marzo embarqué a la joven pareja en un vapor con destino a Tierra del Fuego. El 19 crucé el Estrecho de Magallanes en el Antonia Diez, llegué a Spring Hill en la tarde del 23. En el mes de abril apareció un grupo de indios en el asentamiento, decidimos tomarles algunas medidas para zanjar las discusiones en torno a su tamaño, ellos parecían dudar de nuestros procedimientos, finalmente accedió uno cuya altura era de 5 pies con 8 pulgadas, 40 pulgadas de pecho, 14 pulgadas del codo al brazo, 14 la pantorrilla; había otro que medía 5 pies con 10 pulgadas, como no aceptó someterse a la medición del pecho fue inútil insistir, probablemente algunos onas o indios pedestres de Tierra del Fuego miden más de 6 pies, pero son pocos. Es importante tener en mente que los indios canoeros de aquel lugar poseen una talla muchísimo más pequeña.

Junio de 1898. Siendo junio un mes de invierno en esa parte del mundo, estando controlado el trabajo de la hacienda y acercándose

63 El Oficial Civil de la época era Juan Guillermo Brandt. El soberano era una antigua moneda británica.

64 Dato de interés que confirma la introducción y práctica de costumbres vernáculas entre los inmigrantes británicos, para el caso de los escoceses. el término de mi contrato, decidí regresar a las antiguas colinas floridas de Escocia ${ }^{65}$. Mr. Wales debía subir a Chile ${ }^{66}$ por negocios, por el bien de la compañía acordamos ir juntos a Punta Arenas, aunque él no podría partir hasta que recibiera la correspondencia de Inglaterra, la cual llegaría el 7, llegó el 7 y nada de correspondencia, pasó el 8 con el mismo resultado; por temor a que él perdiera su barco a Valparaíso accedí a esperar la llegada de sus cartas y alcanzarlo después, se fue temprano el 9, su correo llegó ese mismo día al atardecer. En la mañana del 10 salí alrededor de las 6 con 2 buenos caballos, es costumbre en América del Sur alternar caballos cada 2 horas durante un viaje largo o de importancia, era una de aquellas mañanas escarchadas como las que a veces tenemos en Escocia, ha escarchado fuertemente durante varias noches, el suelo parecía de hierro, mi avance era lento al no estar los caballos herrados en esa parte del mundo, sólo pude apresurar la marcha en la playa o cerca de ella, mis pies se enfriaron tantas veces que tuve que desmontar y caminar. Al llegar a Río del Oro hallé que habían dispuesto para mí un caballo descansado, después de un breve descanso continué mi camino, alcancé Gente Grande alrededor de medianoche, cuando tuve el placer de entregarle a Mr. Wales su envío del correo antes de retirarnos a descansar. El día siguiente cabalgamos hacia Porvenir para descubrir que nos habíamos adelantado 2 días al barco que nos cruzaría a Punta Arenas, Mr. Wales se embarcó rumbo a Valparaíso después de unos 2 días en Punta Arenas. Nos volvimos a encontrar algunos años después cuando visitó Dalry por primera vez. Desde el 12 o 13 de junio hasta el 10 de julio permanecí en Punta Arenas, momento en que subí a bordo del Arepso ${ }^{67}$ con destino a Liverpool.

65 La expresión empleada por Blain es Auld Scotlands Heathery Hills (Nota de la traductora).

66 "Subir" o "Ir a Chile" (así como "Venir de Chile") era una expresión común en la época para hacer referencia a viajes hacia y desde la zona central de la República, para enfatizar indirectamente la lejanía y el aislamiento en que se hallaba Magallanes respecto del resto del país.

67 Referencia al Oropesa, uno de los vapores de The Pacific Steam Navigation Company, que hacía el tráfico regular entre el Reino Unido y Sudamérica. 
VOCABULARIO SÉLKNAM

\begin{tabular}{|c|c|c|c|}
\hline Castellano & Sélknam & Castellano & Sélknam \\
\hline $\begin{array}{l}\text { cejas } \\
\text { dientes } \\
\text { molares } \\
\text { oreja } \\
\text { lengua } \\
\text { cabello } \\
\text { carne } \\
\text { talón } \\
\text { muñeca } \\
\text { venas } \\
\text { palma de la mano } \\
\text { dedo } \\
\text { dedo meñique } \\
\text { uñas } \\
\text { brazo } \\
\text { rodilla } \\
\text { pie } \\
\text { cuello } \\
\text { leche } \\
\text { niño } \\
\text { bosque } \\
\text { casa } \\
\text { arco } \\
\text { flecha } \\
\text { carcaj } \\
\text { cuchillo } \\
\text { piedra } \\
\text { ganso } \\
\text { caballo } \\
\text { nieve } \\
\text { lluvia } \\
\text { fuego } \\
\text { venir } \\
\text { después } \\
\text { uña } \\
\text { irse } \\
\text { dame } \\
\text { enojado } \\
\text { nariz } \\
\text { labios } \\
\text { sol } \\
\text { luna } \\
\text { estrella } \\
\text { viento } \\
\text { uno } \\
\text { dos } \\
\text { tres } \\
\text { cuatro } \\
\text { cinco } \\
\text { varios/muchos }\end{array}$ & $\begin{array}{l}\text { otebeachej } \\
\text { orra } \\
\text { orrachikika } \\
\text { sine } \\
\text { chale } \\
\text { ali } \\
\text { yeperr } \\
\text { terr } \\
\text { chinkepaje } \\
\text { jan } \\
\text { chaie } \\
\text { terr } \\
\text { telsiska } \\
\text { kou } \\
\text { siley } \\
\text { aee catche } \\
\text { habe } \\
\text { ote/yowen } \\
\text { chitrn } \\
\text { telken } \\
\text { winche } \\
\text { cowye } \\
\text { ha } \\
\text { jannie } \\
\text { ele } \\
\text { pae } \\
\text { jarri } \\
\text { arrs } \\
\text { gways } \\
\text { jushe } \\
\text { chalwin } \\
\text { jawke } \\
\text { jin } \\
\text { norri } \\
\text { moj } \\
\text { yojon } \\
\text { carcain } \\
\text { tinerrin } \\
\text { orre } \\
\text { semi } \\
\text { kerey } \\
\text { keerene } \\
\text { tells } \\
\text { shens } \\
\text { sosue } \\
\text { soki } \\
\text { souken } \\
\text { conisouke } \\
\text { chinue } \\
\text { pokeren o emili }\end{array}$ & $\begin{array}{l}\text { frutos rojos } \\
\text { bueno } \\
\text { sucio } \\
\text { hambriento } \\
\text { barba } \\
\text { antebrazo } \\
\text { hombro } \\
\text { espalda } \\
\text { garganta } \\
\text { corazón } \\
\text { huevo } \\
\text { grande } \\
\text { estómago } \\
\text { pecho } \\
\text { pasto } \\
\text { hueso } \\
\text { pajarillos } \\
\text { agua } \\
\text { río } \\
\text { capa } \\
\text { muerto } \\
\text { hombre } \\
\text { mujer } \\
\text { niño } \\
\text { zorro } \\
\text { vidrio } \\
\text { canasta } \\
\text { pluma } \\
\text { enfermo } \\
\text { sudor } \\
\text { feo } \\
\text { mentira } \\
\text { beber agua } \\
\text { cerebro } \\
\text { rostro } \\
\text { grasa } \\
\text { tú } \\
\text { ojos } \\
\text { frente } \\
\text { tiento } \\
\text { cantar } \\
\text { bailar } \\
\text { frío } \\
\text { fumar } \\
\text { mar } \\
\text { alto }{ }^{72} \\
\text { cueros } \\
\text { cerco } \\
\text { boca } \\
\text { cururo }\end{array}$ & $\begin{array}{l}\text { wasje } \\
\text { olitch } \\
\text { casperr } \\
\text { carain } \\
\text { caschij } \\
\text { marri } \\
\text { koyen } \\
\text { mayen } \\
\text { sipen } \\
\text { tusl } \\
\text { esl } \\
\text { cajen } \\
\text { jete } \\
\text { sharr } \\
\text { torerr } \\
\text { ko } \\
\text { torteh } \\
\text { chowen } \\
\text { shisken } \\
\text { tolsu } \\
\text { letchen } \\
\text { hoerr } \\
\text { na } \\
\text { wime } \\
\text { wass } \\
\text { ebory } \\
\text { tays } \\
\text { citr } \\
\text { kore } \\
\text { kamisky } \\
\text { ishsen } \\
\text { lik } \\
\text { cholitchen } \\
\text { orlita } \\
\text { kosh } \\
\text { oli } \\
\text { ma } \\
\text { otter } \\
\text { oseri } \\
\text { moine } \\
\text { joon } \\
\text { yewe } \\
\text { kiktow } \\
\text { jawkete } \\
\text { koj } \\
\text { toj } \\
\text { obe } \\
\text { kayen } \\
\text { kaskin } \\
\text { apen } \\
\text { apken }\end{array}$ \\
\hline
\end{tabular}

NOTA: No se ha traducido la palabra: ujer

68 N. de la T.: J.M. Beauvoir propone haghen significando al mismo tiempo "grande y anciano".

69 N. de la T.: el concepto no figura en J.M. Beauvoir, donde sí aparece jeth como "estómago".

70 N. de la T.: J.M. Beauvoir propone chon para "hombre", en tanto que ohrré o okrr especificarían más bien la pertenencia al género masculino (a modo de ejemplo, wuinsokrr significa "perro macho").

71 N. de la T.: joon es el término generalizado para referirse al curandero sélknam, probablemente sugerido por Blain como "el que canta". J.M. Beauvoir propone yewrr como equivalente a "cantar".

72 N. de la T.: probablemente por imitación de tall, "alto" en inglés. En el Diccionario de J.M. Beauvoir figura enkeká como traducción de "alto". 
NOMBRES PROPIOS DE INDÍGENAS SÉLKNAM

\begin{tabular}{|l|l|}
\hline \multicolumn{1}{|c|}{ Hombres } & \\
\hline Hunte & Mujeres \\
Kinshe & Uslipskin \\
Kitem & Cowjoter \\
Gusteley & Estil \\
Kuspi & Kinejaver \\
Supenike & Yesper \\
Jetcker & Parri* \\
Koka & Orrpotel \\
Kutsbe & Olike \\
Choviter & Corre \\
Kilkitchen & Kitow \\
Guari & Jousja \\
Somje & \\
\hline
\end{tabular}

* N. de la T.: salvo Hunte (Honten) y Parri (Parry), ninguno de estos nombres propios aparece en el listado de J.M. Beauvoir.

\section{COMENTARIO}

El vocabulario transcrito es interesante per se, pues viene a sumarse a otros recogidos y publicados con anterioridad, principalmente por el misionero salesiano P. José M. Beauvoir (Los Shelknam Indígenas de la tierra del Fuego. Sus tradiciones, costumbres y lengua. Buenos Aires, 1915), lo que permite una comparación a los especialistas. Del total de 103 vocablos se ha encontrado significado en español para 101; de ellos 80 se corresponden más fonética que gráficamente con los mencionados por Beauvoir. Las diferencias que puedan advertirse por los entendidos deben ser atribuidas al carácter gutural de la lengua sélknam; luego a la dificultad natural que debió enfrentarse el auditor transcriptor: oir, captar los sonidos, interpretarlos, escribirlos de acuerdo a su propio idioma (interpretación fonológica); $y$, por fin, pero no menos importante, a la inhabilidad de Blain debido a su segura instrucción elemental. De cualquier modo, lo mismo ocurrió con otros recopiladores en la generalidad de los casos.

En cuanto a los nombres propios recogidos por Blain, con la excepción de dos, ninguno era conocido hasta ahora. 